\title{
Upaya Pemerintah Kabupaten Lamongan Dalam Melindungi Hak Cipta Batik Tradisional
}

\author{
Enik Isnaini *) \\ ${ }^{*}$ Dosen Fakultas Hukum Universitas Islam Lamongan
}

\begin{abstract}
Batik is a traditional handicraft that contains high value of art and has been exist as the part of Indonesian (partially, Javanese) culture since long. Thus, batik, with its traditional design, including design of Lamongan traditional batik, is one of the wealth of Indonesian culture inheritance. Based on the conclusion, batik needs to be perpetuated, protected, and supported for its long goal development. As the part of the traditional culture that has been passed on since generations, patent rights of batik will be controlled by the state as it's been arranged in Pasal 10 ayat 2 UU No. 19 tahun 2002 about patent rights (copyrights).

The emerge of falsification and imitation of traditional batik connected tightly with the economic and social condition that occurs in our society, in which after economic crisis hit our country, economic and social stability of our people slipped off unarrangedly.

Patent rights protection, based on Undang Undang nomor 19 tahun 2002 about copyrights already accomodating the protection of all creations including traditional batik, yet the protection given by Undang-Undang nomor 19 tahun 2002 about copyrights aren't wisely, or completely, used by the apparatus.
\end{abstract}

Keywords: Batik of Lamongan, Culture Inheritance, Protection of Copyrights.

\section{Pendahuluan}

Pembangunan nasional adalah rangkaian upaya pembangunan yang berkesinambungan yang meliputi seluruh kehidupan masyarakat, bangsa dan Negara untuk melaksanakan tugas mewujudkan tujuan nasional yang termaktup dalam pembukaan Undang-undang Dasar 1945.

Pembangunan ekonomi nasional harus berlandaskan Undang-Undang Dasar 1945 dan pancasila sebagai moral kehidupan bangsa. Sesuai dengan pasal 33 Undang-undang Dasar 1945 yang menyebutkan bahwa perekonomian disusun berdasarkan asas kekeluargaan diharapkan dapat tercipta suatu kesembangan dalam kegiatan usaha besar, menengah dan kecil dalam pola kemitraan usaha. Pada sistem ekonomi yang berasaskan kebersamaan dan kekeluargaan tersebut diharapkan semua pihak dapat bersaing secara kekeluargaan, saling membina agar bersama-sama dapat maju dalam mengembangkan perekonomian nasional yang efisien, sehingga diperlukan adanya perlindungan ekonomi yang dicita-citakan tersebut.

Eksistensi Hak Kekayaan Intelektual ( HKI ) sangat erat dengan dunia perdagangan baik domestik maupun global, untuk itu masyarakat dunia harus berada pada global commitment untuk saling mengakui dan menghargai akan potensi intelektual masing - masing negara. Semakin berkembangnya makna aspek - aspek bisnis dalam karya - karya intelektual telah mengindikasikan terdapatnya dinamika baru berupa potensialnya hasil dari intelektualitas manusia dari rasa, karsa dan cipta.

Hasil karya yang berupa karya intelektual manusia yang memiliki nilai ekonomis yang sangat tinggi, hendaknya juga mendapatkan perlindungan yang sangat memadai. Hal ini ditunjang dengan rasa keadilan untuk mendapatkan apa yang menjadi haknya untuk kesejahteraan sosial dan ekonomi sebagai penghargaan dari hasil intelektualnya.

Batik dalam anggapan umum adalah "sebentuk kain yang memiliki motif-motif tertentu", yang mana motif-motif tersebut telah digunakan beratus tahun (mentradisi) pada sebuah wastra (kain yang bermotif). Pengertian seperti di atas telah menjadi semacam aksioma bahwa batik atau wastra batik adalah motif itu sendiri.

Dari aspek kultural, batik adalah seni tingkat tinggi. Batik tak sekadar kain yang ditulis dengan menggunakan malam (cairan lilin). Pola-pola yang ada di batik, lanjutnya memiliki filosofi yang sangat erat dengan budaya tiap masyarakat. Batik adalah kebanggaan bangsa Indonesia, sebuah 
identitas yang telah diwarisi sejak ratusan tahun lalu. Sayang, identitas ini terancam karena batik-batik ini pun telah diupayakan bangsa lain untuk didaftarkan sebagai warisan nenek moyang mereka.

Sebagai suatu kebudayaan tradisional yang telah berlangsung secara turun temurun, maka Hak Cipta atas seni batik ini akan dipegang oleh negara sebagaimana diatur dalam Pasa1 10 ayat 2 Undang-Undang No. 19 Tahun 2002 tentang Hak Cipta, yaitu : "Negara memegang Hak Cipta atas folklore dan hasil kebudayaan rakyat yang menjadi milik bersama, seperti cerita, hikayat, dongeng, legenda, babad, lagu, kerajinan tangan, koreografi, tarian, kaligrafi, dan karya seni lainnya".

Ketidakmampuan UU Hak Cipta dalam melindungi motif batik yang termasuk ke dalam ekspresi budaya tradisional (folklore), bukan berarti motif batik tradisional tidak dapat dilindungi. Sebab mengingat kedudukannya sebagai motif masyarakat atau folklore yang anonim, maka tidak dapat digolongkan sama seperti karya cipta konvensional yang dilindungi oleh UU Hak Cipta. Motif batik tradisional adalah bagian dari budaya tradisional bangsa Indonesia. Maka motif batik tradisional lebih tepat digolongkan bukan sebagai karya cipta biasa, namun sebagai bentuk dari Ekspresi Budaya Tradisional (Traditional Cultural Expressions/Expressions of Folklore). Menurut Edy Sedyawati, secara umum pengertian Ekspresi Budaya Tradisional atau apa yang disebut dengan istilah folklore adalah segala bentuk ungkapan budaya yang bersifat ekspresif yaitu khususnya ungkapan seni di mana yang penciptanya anonim dan ditransmisikan secara lisan ${ }^{23}$.

Walaupun Indonesia telah memiliki Undang - undang Hak Cipta, namun masalah mengenai royalti, belum banyak dipahami. Royalti adalah bentuk pembayaran yang dilakukan kepada pemilik hak cipta atau pelaku ( performer), karena tidak menggunakan kepemilikannya. Royalti yang dibayarkan didasarkan pada prosentase yang disepakati dari pendapatan yang timbul dari penggunaan kepemilikan atau dengan cara lainnya. ${ }^{24}$

Adapun yang melatarbelakangi munculnya masalah - masalah yang berkaitan dengan permasalahan hak cipta di Indonesia antara lain :

1. Disinyalir bahwa masyarakat Indonesia dalam konteks pergaulan internasional dikenal sebagai masyarakat yang kurang menghargai hak cipta. ${ }^{25}$

2. Hak cipta merupakan hak eksklusif ( khusus ), yang mana bila dilihat dari akar budaya bangsa Indonesia, dapat dikatakan tidak mempunyai akar dalam kebudayaan Indonesia dan juga tidak terdapat dalam sistim hukum adat. ${ }^{26}$ Nilai - nilai falsafah yang mendasari pemilikan individu terhadap suatu karya cipta manusia baik dalam bidang ilmu, sastra, maupun seni adalah nilai budaya barat yang menjelma dalam sistim hukumnya. ${ }^{27}$

3. Realitas di masyarakat masih menunjukkan banyaknya pelanggaran hak cipta dan disinyalir telah mencapai tingkat yang membahayakan dan dapat merusak tatanan kehidupan masyarakat pada umumnya terutama kreatifitas untuk mencipta. Disisi lain usaha yang dilakukan oleh pemerintah Indonesia dalam rangka perlindungan terhadap Karya Cipta ternyata belum membuahkan hasil yang maksimal, meskipun UU Hak Cipta dalam memberikan perlindungan hukum terhadap suatu karya cipta maupun terhadap hak dan kepentingan pencipta dan pemegang hak cipta sudah cukup memadai bahkan dapat dikatakan berlebihan. Realitasnya, pelanggaran hak cipta masih terus mengejala dan seolah - olah tidak dapat ditangani oleh aparat penegak hukum. Berbagai macam pelanggaran terus berlangsung seperti pembajakan terhadap karya cipta, mengumumkan, mengedarkan maupun menjual karya cipta orang lain tanpa seizin pencipta atau pemegang hak cipta $^{28}$.

4. Meskipun kelemahan - kelemahan dalam substansi maupun struktur hukum telah mengalami perbaikan dari waktu ke waktu, namun aspek budaya hukum UU Hak Cipta belum mendapatkan perhatian yang serius. Undang - undang itu akan bekerja dengan baik

\footnotetext{
${ }^{23}$ Edy Sedyawati, Budaya Indonesia: Kajian Arkeologi, Seni. Dan Sejarah, P.T.Raja Grafindo Persada,Jakarta,2007.

${ }^{24}$ Copyrihgt royalties for Music and sound Recordings, Chapter . u.s, Congress, Office of Technologi Assessment, Copyright and Home Copying: Technology Challenges the Law. OTA- CTT-422,( Wasington, DC: U.S. Government Printing Office, Oktober 1989 ), hlm.103.

${ }^{25}$ Budi Agus Riswandi Dan M. Syamsudin,Op. Cit, hlm.192,

${ }^{26}$ Hilman Hadikusuma, Pengantar Ilmu Hukum Adat Indonesia, Mandar Maju, Bandung, 1992,hlm 32.

${ }^{27}$ Salman Luthan, Delik Hak Cipta,.Makalah Diskusi Jurusan Hukum Pidana FH Universitas Islam Indonesia. Tanggal 24 Agustus 1989, hlm 36.

${ }^{28}$ Sophar Maru Hutagalung, Hak Cipta Kedudukan dan Peranannya di dalam Pembangunan, Akademi Presindo, Jakarta, 1994, hlm.2.
} 
jika budaya hukum masyarakatnya mendukung dan budaya mengabaikan hak cipta berubah ke budaya menghormati hak cipta. ${ }^{29}$

Bentuk - bentuk pelanggaran terhadap hak milik intelektual, yaitu berupa: pemalsuan; pembajakan ; penyadapan dan pembocoran informasi rahasia ; persaingan tidak jujur ; turut menawarkan serta memperdagangkan hasil pemalsuan ; dan sebagainya. Terjadinya pelanggaran itu kini dipandang tidak hanya merugikan si pemilik hak saja, tetapi juga dapat merugikan kepentingan umum, misalnya merugikan di bidang perpajakan, perindustrian, konsumen, serta tatanan sosial, hukum dan ekonomi secara luas

Mendasarkan pada uraian tersebut di atas, kiranya dapat dipahami bahwa masalah dalam perlindungan karya cipta batik tradisional adalah belum adanya sistem perlindungan yang tepat untuk melindungi karya cipta batik tradisional dan pengrajin yang menghasilkan karya-karyanya yang dapat tergolong dalam cipta pribadi.

Bertitik tolak dari latar belakang tersebut diatas, maka ada permasalahan yang perlu dikaji, yaitu sebagai berikut:

a. Bagaimana upaya Pemda dalam melindungi hak cipta Hak Cipta Batik tradisional ?

b. Hambatan - hambatan yuridis dan non yuridis apa untuk mendapatkan perlindungan?

\section{Kajian Teori}

\section{A. Pengertian Batik.}

Sejak dulu hingga sekarang, batik mempunyai kedudukan yang penting dalam masyarakat Jawa, baik yang bertempat tinggal di daerah Pantai Utara, maupun yang berada di daerah pedalamanPulau Jawa. Digunakan untuk pakaian sehari-hari dan dipakai sebagai busana dalam upacara-upacara tertentu. Dalam upacara-upacara yang dilakukan untuk menandai siklus kehidupan manusia sejak bayi dalam kandungan tujuh bulan hingga menjelang kematian, fungsi batik senantiasa menyertainya.

Batik dalam anggapan umum adalah "sebentuk kain yang memiliki motif-motif tertentu", yang mana motif-motif tersebut telah digunakan beratus tahun (mentradisi) pada sebuah wastra (kain yang bermotif). Pengertian seperti diatas telah menjadi semacam aksioma bahwa batik atau wastra batik adalah motif batik itu sendiri.

Dari aspek kultural, batik adalah seni tingkat tinggi. Batik tak sekadar kain yang ditulis dengan menggunakan malam (cairan lilin). Pola-pola yang ada di batik, lanjutnya memiliki filosofi yang sangat erat dengan budaya tiap masyarakat. Batik adalah kebanggaan bangsa Indonesia, sebuah identitas yang telah diwarisi sejak ratusan tahun lalu. Sayang, identitas ini terancam karena batik-batik ini pun telah diupayakan bangsa lain untuk didaftarkan sebagai warisan nenek moyang mereka.

Batik, pada mulanya tidak seperti yang kita kenal sekarang. Sebentuk wastra batik memilki kesejahteraan dan tradisi yang cukup lama. Dalam masa keemasan kesejarahannya, watra batik sempat menjadi kain yang sangat eksklusif karena wastra tersebut hanya diperuntukkan bagi kalangankeluarga kerajaan atau hanya dipergunakan pada upacara-upacara tertentu. Bahkan, konon wastra batik memiliki cerita-cerita mistik dan menakjubkan yang mengikuti motif-motif sakral yang tercipta.

Tinjauan mengenai Hak Cipta Menurut UU No.19 Tahun 2002 tentang Hak Cipta.

Pasal 1 angka 1 Undang - undang Hak Cipta No.19 Tahun 2002, menyebutkan bahwa :

"Hak cipta adalah hak eksklusif bagi pencipta maupun penerima hak untuk mengumumkan atau memperbanyak ciptaannya atau memberi izin untuk itu dengan tidak mengurangi pembatasan pembatasan menurut peraturan perundang - undangan yang berlaku “

Dilihat dari pengertian diatas terdapat dua unsur yang penting dalam hak cipta yang terdapat pada pasal 1 Undang - undang Hak Cipta 2002 Pertama, hak yang dapat dipindahkan dialihkan kepada pihak lain dan kedua hak moral yang dalam keadaan bagaimanapun dengan jalan apapun tidak dapat

\footnotetext{
${ }^{29}$ Ibid.
} 
ditinggalkan dari padanya seperti : pengumuman karyanya, menetapkan judulnya, mencantumkan nama sebenarnya atau samarannya dan mempertahankan keutuhan atau integritas ceritannya.

bahwa :

Hak cipta sendiri menurut ketentuan Pasal 1 ayat (1) UU Nomor 19 Tahun 2002 diartikan

" Hak eksklusif bagi pencipta atau penerima hak untuk mengumumkan atau memperbanyak ciptaannya atau memberikan izin untuk itu dengan tidak mengurangi pembatasan - pembatasan menurut peraturan perundang - undangan yang berlaku".

Ketentuan Pasal 1 ayat (1) Undang - undang Hak Cipta dapat dipertegas dan diperkuat lagi dengan ketentuan pasal 2 ayat (1) Undang - undang No.19 Tahun 2002 tentang Hak Cipta yang menyatakan bahwa :

" Hak cipta merupakan hak eksklusif bagi pencipta atau pemegang hak cipta untuk mengumumkan atau memperbanyak ciptaannya, yang timbul secara otomatis setelah setelah sesuatu ciptaan dilahirkan tanpa mengurangi pembatasan menurut peraturan perundang - undangan yang berlaku".

Dalam kerangka ciptaan yang mendapatkan hak cipta setidaknya harus memperhatikan beberapa prinsip - prinsip dasar hak cipta, yakni: ${ }^{30}$

1. Yang dilindungi hak cipta adalah ide yang telah berwujud dan asli. Salah satu prinsip yang paling fundamental dari perlindungan hak cipta adalah konsep bahwa hak cipta hanya berkenan dengan bentuk perwujudan dari suatu ciptaan misalnya buku, sehingga tidak berkenaan atau tidak berurusan dengan substansinya. Dan prinsip dasar ini telah melahirkan dua sub prinsip, yaitu:

a. Suatu ciptaan harus mempunyai keaslian (orisinil) untuk dapat menikmati hak - hak yang diberikan undang - undang keaslian, sangat erat hubungannya dengan bentuk perwujudan suatu ciptaan.

b. Suatu ciptaan, mempunyai hak cipta jika ciptaan yang bersangkutan diwujudkan dalam bentuk tertulis atau bentuk material yang lain. Ini berarti bahwa suatu ide atau suatu pikiran atau suatu gagasan atau cita - cita belum merupakan suatu ciptaan.

2. Hak cipta timbul dengan sendirinya (otomatis). Suatu hak cipta eksis pada saat seorang pencipta mewujudkan idenya dalam suatu bentuk yang berwujud yang dapat berupa buku. Dengan adanya wujud dari suatu ide, suatu ciptaan lahir. Ciptaan yang dilahirkan dapat diumumkan (to make public/ openbaarmaken) dan dapat diumumkan. Suatu ciptaan yang tidak diumumkan, hak ciptanya tetap ada pada pencipta.

3. Suatu ciptaan tidak perlu diumumkan untuk memperoleh hak cipta. Suatu ciptaan yang diumumkan maupun yang tidak diumumkan (published/ unpublished work) kedua -duanya dapat memperoleh hak cipta.

4. Hak cipta suatu ciptaan merupakan suatu hak yang diakui hukum (legal right) yang harus dipisahkan dan harus dibedakan dan penguasaan fisik suatu ciptaan.

5. Hak cipta bukan hak mutlak (absolut). Hak cipta bukan suatu monopoli mutlak melainkan hanya suatu limited monopoly. Hal ini dapat terjadi karena hak cipta secara konseptual tidak mengenal konsep monopoli penuh, sehingga mungkin saja seorang pencipta menciptakan suatu yang sama dengan ciptaan yang tercipta terlebih dahulu.

Mengacu pada UUHC, maka ciptaan yang mendapat perlindungan hukum ada dalam lingkup seni, sastra dan ilmu pengetahuan. Dan tiga lingkup ini undang - undang merinci lagi diantaranya seperti yang ada pada ketentuan pasal 12 Undang -undang No.19 tahun 2002 tentang Hak Cipta.

\section{Pembahasan}

\section{A. Upaya Pemkab Lamongan dalam melindungi Hak Cipta Batik Tradisional.}

Sejak dulu hingga sekarang, batik mempunyai kedudukan yang penting dalam masyarakat Jawa, baik yang bertempat tinggal di daerah Pantai Utara, maupun yang berada di daerah pedalamanPulau Jawa. Digunakan untuk pakaian sehari-hari dan dipakai sebagai busana dalam

\footnotetext{
${ }^{30}$ Budi Agus Riswandi danM.Syamsudi, Op.Cit, hlm.8-10
} 
upacara-upacara tertentu. Dalam upacara-upacara yang dilakukan untuk menandai siklus kehidupan manusia sejak bayi dalam kandungan tujuh bulan hingga menjelang kematian, fungsi batik senantiasa menyertainya.

Dari aspek kultural, batik adalah seni tingkat tinggi. Batik tak sekadar kain yang ditulis dengan menggunakan malam (cairan lilin). Pola-pola yang ada di batik, lanjutnya memiliki filosofi yang sangat erat dengan budaya tiap masyarakat. Batik adalah kebanggaan bangsa Indonesia, sebuah identitas yang telah diwarisi sejak ratusan tahun lalu. Sayang, identitas ini terancam karena batik-batik ini pun telah diupayakan bangsa lain untuk didaftarkan sebagai warisan nenek moyang mereka.

Batik, pada mulanya tidak seperti yang kita kenal sekarang. Sebentuk wastra batik memilki kesejahteraan dan tradisi yang cukup lama. Dalam masa keemasan kesejarahannya, watra batik sempat menjadi kain yang sangat eksklusif karena wastra tersebut hanya diperuntukkan bagi kalangankeluarga kerajaan atau hanya dipergunakan pada upacara-upacara tertentu. Bahkan, konon wastra batik memiliki cerita-cerita mistik dan menakjubkan yang mengikuti motif-motif sakral yang tercipta.

Sebagai suatu kebudayaan tradisional yang telah berlangsung secara turun temurun, maka Hak Cipta atas seni batik ini akan dipegang oleh negara sebagaimana diatur dalam Pasa1 10 ayat 2 Undang-Undang No. 19 Tahun 2002 tentang Hak Cipta, yaitu : "Negara memegang Hak Cipta atas folklore dan hasil kebudayaan rakyat yang menjadi milik bersama, seperti cerita, hikayat, dongeng, legenda, babad, lagu, kerajinan tangan, koreografi, tarian, kaligrafi, dan karya seni lainnya".

Salah satu yang harus dilindungi oleh negara adalah Batik Tradisional di desa Sendang Agung Kabupaten Lamongan. Sesuai sejarahnya yang tidak dapat dipisahkan dari budaya dan kehidupan sehari-hari masyarakat, maka batik memiliki kandungan makna filosofi dalam setiap motifnya, motif batik tradisional desa Sendang Agung mengandung makna filosofi ${ }^{31}$.Motif batik tradisional desa Sendang Agung ada 30 motif yaitu : Blantongan, Kota'an, Manuk Sangget, Bolo-bolo, Burung Walet, Pathi, Ijon-ijon, Slempang Gunungan, Slempang Rante, Kembang Kipas, Sido Makmur, Slempang Lang Semangggi, Kawung Manuk, Slempang manuk Gede, Manuk Blekok, Manuk Akeh, Truntum Kuncoro, Putihan Petetan, Patem, Slempang Roro Kepet, Burung Merak, Enom Kantil, Rambate, Kerang Pesisir, Kipas Raja, Kembang sungsang, Slempang Lungkik, Pulau Manuk Enom Kathel, Bior, Pulaunan Manuk Biru.

Upaya-upaya yang dilakukan Pemkab Lamongan ,dalam hal ini dilakukan oleh Dinas koperasi, Industri dan Perdagangan Pemkab Lamongan dalam melindungi batik tradisional,menurut bapak Bambang Handoko ${ }^{32}$, antara lain:

- Pembinaan.Pembinaan ini diikuti oleh pengusaha Batik Tradisional yang ada di Paciran kab.Lamongan.

- Pelatihan. Pelatihan disini berupa cara membatik,cara pewarnaan, bahan-bahan yang baik digunakan untuk membuat batik.

- Dana bergulir atau istilahnya Fast Refalfing. Dana ini diberikan untuk para pembatik.Dana ini berupa pinjaman uang dan ini tidak untuk perorangan tetapi untuk kelompok.Tiap kelompok bisa dapat pinjaman Rp.10.000.000,00 sampai Rp.50.000.000,00 tergantung kemampuan kelompok. Dana tersebut bisa diangsur dalam waktu satu (1) tahun. Kalau pinjaman sudah lunas dapat mengajukan pinjaman lagi.

- Ikut Pameran.Pameran itu untuk sementara masih dilakukan disekitar pulau Jawa.

- Menerapkan seragam batik di lingkungan Pemda Kab. Lamongan.

Untuk melaksanakan kegiatan pembinaan dan pelatihan, dana yang digunakan adalah dana berasal dari dana APBD Pemkab Lamongan, sedang dan yang digunakan untuk pemberian pinjaman pada pengusaha batik atau kepada pembatik adalah Dinas Koperasi, Industri dan perdagangan Kabupaten Lamongan bekerja sama dengan Bank Daerah Kabupaten Lamongan.

\footnotetext{
${ }^{31}$ Wawancara dengan sesepuh Desa Sendang Agung, bapak Sulaiman, tanggal 3 Januari 2012.

${ }^{32}$ Wawancara dengan Kasi Teknologi dan Produksi ,Dinas Koperasi, Industri dan Perdagangan, Kab.Lamongan,Bapak Bambang Handoko, pada tanggal 10 Januari 2012
} 


\section{B. Hambatan -hambatan yuridis dan non yuridis dalam mendapatkan perlindungan Hak Cipta.}

Berdasarkan hasil pengamatan di lapangan diperoleh data bahwa batik tiruan banyak diperjual belikan dikalangan Pedagang-pedagang kecil, Sedangkan para pedagang batik resmi,tidak menjual produk batik tiruan atau jiplakan. Informasi yang diperoleh dari Pedagang-pedagang kecil yang menjual batik tiruan atau jiplakan, menyatakan mereka menjual batik tiruan atau jiplakan karena adanya berbagai alasan, diantaranya karena:

a. Faktor Ekonomi

Faktor ekonomi ini menjadi faktor pendorong utama mereka menjual batik tiruan, sebagaimana dikatakan oleh ibu Harti penjual batik tiruan atau jiplakan yang berada di kawasan pasar Lamongan menyatakan, "Karena tidak memiliki hasil yang memadai untuk membiayai penghidupan sehari-hari, saya terpaksa menjual batik tiruan atau jiplakan karena keuntungan yang diperoleh cukup lumayan

Berdasarkan pengamatan di lapangan diperoleh gambaran bahwa harga Batik tiruan rata-rata dijual dengan harga Rp. 40.000,- (empat puluh ribu rupiah) per kemeja atau per potong, sedangkan harga batik asli paling murah adalah Rp.150.000 ,- (seratus lima puluh ribu rupiah) per potong. Perbedaan harga inilah yang mendorong masyarakat untuk membeli batik tiruan atau jiplakan.

\section{b. Faktor Sosial Budaya}

Masyarakat kita secara sosial dan budaya terbiasa untuk membeli produk-produk tidak asli, terutama untuk produk batik. Masyarakat kita tidak memperdulikan apakah produk yang dibeli asli ataukah tidak, yang penting harganya murah

Disamping masalah harga, masyarakat tidak memiliki budaya malu untuk membeli atau mempergunakan produk - produk tiruan atau palsu khususnya produk batik. Budaya tidak malu menggunakan produk tiruan atau palsu didukung oleh kurangnya penghargaan masyarakat terhadap hasil karya orang lain.

c. Faktor Sumber Daya Manusia (SDM)

Faktor lain yang mengakibatkan terjadinya pelanggaran hukum adalah karena sumber daya manusia dimana mereka tidak mengetahui secara pasti mengenai batik yang asli dan tidak asli ini adalah dampak sumber daya manusia yang kurang memahami tentang UUCH dan ini harus diperhatikan oleh pihak-pihak terkait dalam proses sosialisasi harus secara langsung bermasyarakat baik berupa seminar maupun dialog untuk mewujudkan masyarakat yang mengerti tentang undang-undang yaitu UUHC.

Selain faktor diatas kendala penegakan hukum UUHC dan kebijakan pada pedagnag batik di kota Lamongan adalah masalah sosialisasi yang kurang baik, pemerintah pusat dan pemerintah daerah, karena mereka tidak mengetahui dengan jelas mengenai pelaksanaan undang -undang Hak Cipta, sehingga mereka menganggap belum ada kebijakan-kebijakan yang dapat membantu pedagang, maksudnya memberi kesempatan pada pedagang dalam menjual hasil dagangan mereka .

d. Rendahnya Sanksi Hukum Yang Dijatuhkan.

Sanksi hukum terhadap pemalsuan batik dikenakan hanya pada Penjiplak atau pemalsu dan belum sampai kepada konsumen yang membeli produk jiplakan. Pengenaan sanksi yang hanya dikenakan kepada pelaku pemalsuan dan penjual saja sesuai dengan keterangan yang diberikan oleh : Bowo Susilo Perwira Polisi yang bertugas menangani kasus pemalsuan. Pernyataan dari pihak kepolisian ini dibenarkan oleh para penjual batik, bahwa selama ini penegakan hukum dibidang hakcipta, khususnya tentang batik masih belum berlaku secara menyeluruhdan bersifat tebang pilih. Apabila kita berpedoman pada Undang - Undang Hak Cipta, maka sanksi hukum yang dikenakan pada pembajak lebih ditekankan pada sanksi yang bersifat denda, belum mengarah pada sanksi yang bersifat pemidanaan. 


\section{Penutup}

\section{A. Kesimpulan}

1. Berdasarkan uraian dalam hasil penelitian dan pembahasan, maka dapat diambil beberapa kesimpulan sebagai berikut: Upaya yang dilakukan Pemkab Lamongan, dalam hal ini dilaksanakan oleh Dinas Koperasi dan Perdagangan Pemkab Lamongan dalam melindungi Batik Tradisional adalah melakukan pembinaan yang ditujukan pada pengusaha Batik Tradisional, Pelatihan - pelatihan, Pemberian dana bergulir atau Fast Refalfing yang diberikan untuk para pembatik dan pengusaha batik,Ikut pameran-pameran, dan menerapkan seragam batik di lingkungan Pemda Lamongan.

2. Kendala yang dihadapi oleh pemegang Hak Cipta Batik Tradisional di Paciran Kab. Lamongan dalam upaya pengembangan usaha dan kreativitas diantaranya yaitu kultur masyarakat Indonesia khususnya di daerah-daerah yang kurang mengenal hak atas kekayaan intelektual, adanya kebiasaan masyarakat meniru atau menjiplak orang lain telah berlangsung lama dan selama ini tidak ada yang menuntut dan tidak ada sanksi terhadap perbuatan tersebut dan kondisi ekonomi masyarakat masih lemah sehingga mengakibatkan daya beli masyarakat terhadap produk asli/original sangat kurang serta kinerja aparat penegak hukum yang kurang profesional dalam menangani produk-produk desain industri tradisional hasil tiruan, jiplakan atau bajakan.

\section{B. Saran}

Dalam penelitian ini, penulis memberikan saran-saran sebagai berikut:

1. Perlunya sosialisasi dan penyuluhan mengenai undang-undang nomor 19 tahun 2002 tentang Hak Cipta oleh pihak-pihak terkait, dalam hal ini Direktorat Jendral HKI terhadap para pencipta ataupun aparat penegak hukum.

2. Pemerintah dalam hal ini Mentri Depkumham perlu untuk segera membentuk Dewan Hak Cipta yang diamanatkan dalam Pasal 48 undang-undang nomor 19 tahun 2002 tentang Hak Cipta.

3. Perlu peningkatan kesadaran masyarakat untuk menghargai hak cipta orang lain melalui penegakan hukum pidana di bidang hak cipta secara optimal oleh pihak-pihak terkait.

\section{DAFTAR PUSTAKA}

Ahmad Zein Umar Purba, Pokok-pokok Kebijakan Pembangunan Sistim HKI Nasional, Hukum Bisnis, Jurnal, Vol.13 (April 2001),hal.8

Budi Agus Riswandi dan M. Syamsudin, Hak Kekayaan Intelektual dan Budaya Hukum, Rajawali Grafindo Persana, Jakarta, 2004,hlm 193.

Copyrihgt royalties for Music and sound Recordings, Chapter . u.s, Congress, Office of Technologi Assessment, Copyright and Home Copying: Technology Challenges the Law. OTA-CTT - 422,( Wasington, DC: U.S. Government Printing Office, Oktober 1989 ), hlm.103.

. Etty Susilowati, S.H, M.S, Bunga Rampai HKI, Semarang, 23 Januari 2010

Gunawan Wijaya, Alternatif Penyelesaian Sengketa, Rajawali Grafindo Persada, Jakarta, 2001,hlm 1.

Hanafi, Tindak Pidana Hak Cipta dan Problematika Penegakan Hukumnya, dalam Insan Budi Maulana,dkk, Kapita Selekta Hak Kekayaan Intelektual, Pusat Studi Hukum Universitas Islam Indonesia, 2000,hlm.189

Hilman Hadikusuma, Pengantar Ilmu Hukum Adat Indonesia, Mandar Maju, Bandung, 1992,hlm 32.

Salman Luthan, Delik Hak Cipta,. Makalah Diskusi Jurusan Hukum Pidana FH Universitas Islam Indonesia. Tanggal 24 Agustus 1989, hlm 36.

Mihammad Djumhana dan R. Djubaedillah, Hak milik Intelektual : Sejarah, Teori, dan prakteknya di Indonesia, Citra Aditya Bakti, Bandung,2003, hal 24

M. Syamsudin, Nilai-nilai Karya Cipta dan Problematika Perlindungan Hukumnya, Jurnal hukum No. 16 Vol.8 Maret 2001,hlm.128 